\title{
The Naturalist Heldur Sander Celebrates His 75th Birthday
}

Heldur Sander is currently one of the leading Estonian dendrologists, the "grand old man" of Estonian dendrology, who has also taken a keen interest in other significant questions of the history of science, predominantly related to the history of botanical research. However, trees, their "biographies", as well as the history of dendrology in Estonia and beyond has captured his special attention throughout decades.

A member of the Estonian Association for the History and Philosophy of Science, Heldur Sander was born on 24 November 1946 in a separate settlement on the outskirts of the village of Ageri, previously known as Lambaküla, in Järva County. The farm house, where he was born and where his parents had settled after getting married, was located on a former bog island near the edge of the local bog. After leaving Lambaküla, the family moved to Koeru, where Heldur attended the local school. At an early age, he developed a bone disease, which made his bones very fragile and prone to injuries. Partly due to this illness, he became very fond of books and began to read extensively. However, the illness did not force him to give up physical exercises and sports entirely. Already at such an early age he decided to challenge his fate and act against all odds.

At first, life did not go smoothly for him. After two years of studying at Tihemetsa Technical School he realized that this school was not for him. Then he worked for a while as a construction worker, while studying at Paide Distance Learning High School at the same time. During that period he occasionally also earned living as an animal attendant, an overseer of cattle transported by train from Estonia to Uzbekistan and Kazakhstan. This was quite a widely spread side activity among intellectuals in Estonia in Soviet times.

In 1968, Heldur Sander passed the admission exams and began to study geography at the University of Tartu. His studies became intermittent due to health and other issues, so he did not graduate from the university until 1975. During the student years in Tartu he met his future wife, the botanist-lichenologist Enel Jaanits (later Sander, 1953-2015), daughter of the well-known Estonian archeologist Lembit Jaanits (1925-2015). After graduating from the university, Heldur Sander held a researcher's position at Tallinn Botanic Garden. His first superior at the botanical garden was Andres Tarand (b. 1940), then head of a department, later Prime Minister of Estonia (1994-1995). Heldur Sander worked at Tallinn Botanic 
Garden for more than twenty years until 1997. His research interests at that time were mainly related to the study of the natural environment of Tallinn through history. During the last two years at the botanical garden, his main research interest was dedicated to Estonian arboreta and manor parks. He has studied land use in Tallinn, the city's forests, non-native dendroflora as well as native trees, tree felling and planting, and the development of urban landscaping. During his period of working at Tallinn Botanic Garden, Heldur Sander and his co-authors (the most frequent of whom was Jüri Elliku, 1947-2011) completed almost 140 scientific and popular science papers in different forms, ranging from separate publications to scientific articles in reputable journals. Heldur Sander's talent as a researcher and publicist became especially evident during the so-called "Ginkgo affair", a social dispute around a rare Ginkgo biloba tree in Tallinn downtown in the middle of the 1980s. Besides being a thorough researcher, he is also a writer with an easy-to-read style.

In 1996, Heldur Sander attended a three-month professional development course at the Danish Forest and Landscape Research Institute. In 1998, he joined the Institute of Forestry of the Estonian University of Life Sciences, where he worked until his retirement in 2010. The most significant works of that period are co-authored with another distinguished researcher in the history of forestry Toivo Meikar (b. 1947). In 1998, Heldur Sander defended his master's degree in landscape science and in 1999-2004 he studied for a doctorate at the University of Life Sciences.

Heldur Sander has published more than 500 articles and individual publications in various journals and collections, of which 150 are more valuable according to the author himself. Conducting research has always being a delightful enterprise for him. Some of his research works are in fact short monographs, e.g., the preprints Tallinna maakasutuse struktuur ('Structure of urban land use in Tallinn', 1987) or an overview of the scientific activities of Eduard Viirok (2000), the first researcher of Tallinn's dendroflora. Heldur Sander has also been a frequent contributor to the journal Acta Baltica Historiae et Philosophiae Scientiarum (ABHPS). His articles 'The Learned Gardeners of the Botanical Gardens of the University of Tartu and Their Activities (1803-1918)' was published in ABHPS, vol. 2 (2014), no. 1; 'Günther Weber, Benjamin Sass and Eduard Philipp Körber, Lutheran Pastors of Voonnu: Sacred Trees, Felling of a Sacred Oak and Planting of an Oak to Herald Freedom for the Estonian People' in ABHPS, vol. 6 (2018), no. 1; and 'The Life and Activities of Professor Gottfried Albrecht Germann, the First Natural History Professor at the University of Tartu' in ABHPS, vol. 


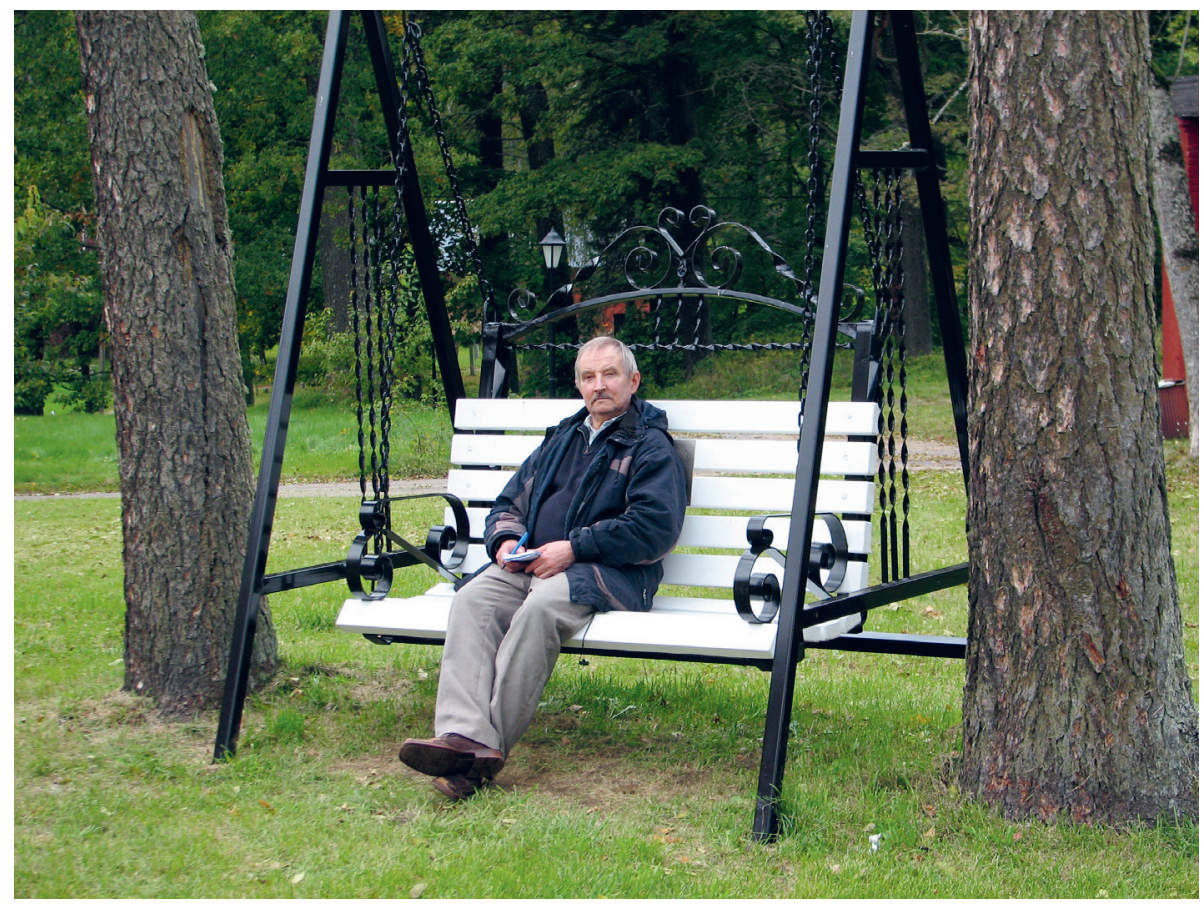

Photo 1. Heldur Sander (photo from personal collection).

7 (2019), no. 3. As a token of recognition, Heldur Sander was awarded the Ignatsi Jaak Medal by B. G. Forselius Society and the third Prize for Popularizing Science, issued by Archimedes Foundation of Estonia.

Heldur Sander and his two children were severely affected by the long illness and departure of his spouse and their mother Enel Sander in 2015, a year before the 40th anniversary of their marriage. Despite his own poor health, Heldur was also his wife's caregiver for many years. At the same time, she was very understanding and supported Heldur in his research, which is something that he values very much.

In the past decade, following his retirement, the scope of the Heldur Sander's research as well as the geographical reach of his international cooperation in the field of the history of natural science has even widened. Despite his disabilities that have progressively worsened, he has continued to carry out research and cooperate with dendrologists and science historians from different countries both in Europe and beyond, such as Finland, Denmark, Germany, France, the Netherlands, Russia, Poland, Japan, Hong Kong, Brazil, etc. Heldur Sander is 
an example of a dedicated researcher who truly loves his research above all else, without pursuing personal gain.

We wish him strength, good health and optimism for years to come!

\section{Mait Talts}

